\title{
Pembuatan Nugget Ikan (Fish Nugget) Sebagai Salah Satu Usaha Deferensiasi Pengolahan Ikan Di Sekolah Alam Banyu Belik
}

\author{
Dewi Kresnasari ${ }^{1}$, Dian Mustikasari ${ }^{2}$, dan Any Kurniawati ${ }^{3}$ \\ 1,2,3 Fakultas Sains dan Teknologi, Universitas Nahdlatul Ulama Purwokerto \\ Email : ${ }^{1}$ dewiks2903@gmail.com, ${ }^{2}$ dmmustikasari@gmail.com, ${ }^{3}$ anyskel@gmail.com
}

\begin{abstract}
Indonesia has a huge potential for fisheries resources, but the level of fish consumption in Indonesia is still low. One of the efforts that can be done to increase fish consumption is by forming a habit of eating fish in school-age children. The outcomes achieved in PKM activities are 1) Increasing student knowledge, especially fish nuggets, 2) Parents can create catfish nuggets. The method used is the transfer of knowledge and technology accompanied by group learning practices. The activity was attended by 37 elementary school students and 20 PAUD Banyu Belik natural school students. The activity was carried out through several stages, namely: the socialization of fond of eating fish, filling out questionnaires, the distribution of let's eat fish, the practice and the distribution of catfish nuggets. This dedication activity succeeded in giving students an understanding of the importance of consuming fish and processed fish food as food with high nutritional value. Another technological finding is an improvement in packaging models that are more environmentally friendly.
\end{abstract}

Keywords: PKM; Socialization; Catfish; Nugget.

\begin{abstract}
Abstrak
Indonesia memiliki potensi sumber daya perikanan yang sangat besar, tetapi tingkat konsumsi ikan di Indonesia masih rendah. Salah satu upaya yang dapat dilakukan untuk meningkatkan konsumsi ikan adalah dengan membentuk sikap gemar makan ikan pada anak usia sekolah. Adapun luaran yang telah dicapai pada kegiatan PKM yaitu 1) Meningkatkan pengetahuan siswa terutama produk nugget ikan, 2) Orang tua dapat menciptakan produk nugget lele. Metode yang digunakan adalah dengan transfer ilmu dan teknologi disertai praktek pembelajaran kelompok. Kegiatan diikuti oleh 37 siswa Sekolah Dasar dan 20 siswa PAUD Sekolah Alam Banyu Belik. Kegiatan dilakukan melalui beberapa tahapan, yaitu: sosialisasi gemar makan ikan, pengisian kuesioner, pembagian pin ayo makan ikan, praktek serta pembagian nugget lele. Kegiatan ini berhasil memberikan pemahaman kepada siswa pentingnya mengkonsumsi ikan dan makan olahan ikan dengan nilai gizi yang tinggi. Temuan teknologi lainnya yaitu perbaikan model pengepakan yang lebih ramah lingkungan.
\end{abstract}

Kata Kunci: PKM; Sosialisasi; Ikan Lele; Nugget. 


\section{Pendahuluan}

Makanan merupakan salah satu kebutuhan pokok manusia. Hal terpenting yang perlu diperhatikan yaitu masalah ketercuku $\neg$ pan gizinya dalam makanan. Berbagai permasalah gizi pada anak sekolah dapat terjadi terutama karena kekurangan asupan zat gizi makro seperti energi, protein dan lemak, maupun zat gizi mikro (vitamin dan mineral). Salah satu jenis bahan makanan sehat adalah ikan. Ikan menyediakan berbagai protein, lemak (asam lemak omega 3), vitamin (vitamin A, vitamin $\mathrm{D}$, vitamin $\mathrm{B} 6$, vitamin $\mathrm{B} 12$ ), dan mineral (zat besi, yodium, selenium, seng, dan fluor) yang dibutuhkan oleh tubuh (Effendie, 2002). Berbagai keuntungan yang diperoleh ketika mengkonsumsi ikan adalah : terpenuhinya kebutuhan 10 asam lemak esensial, menurunkan tekanan darah, menurunkan kadar kolesterol, menurunkan berat badan, merangsang pertumbuhan otak dan kecerdasan otak, menyehatkan mata, mencegah keriput dan proses penuaan kulit, serta mencegah penyakit berat seperti jantung, kanker payudara, dan kanker prostat (WHO, 2003).

Pada tahun 2015 menurut Erawan dan Boer (2018), tingkat konsumsi ikan di Indonesia hanya $40 \mathrm{~kg} / \mathrm{kapita} / \mathrm{tahun}$. Peningkatan ini konsumsi ikan dari tahun ke tahun tidak banyak mengalami peningkatan. Pada tahun 2010 tercatat tingkat konsumsi ikan di Indonesia sebesar 30,17 kg/kapita/tahun dan tahun 2013 sebesar 35,62 kg/kapita/tahun dan tahun 2014 lalu sebesar $38 \mathrm{~kg} / \mathrm{kapita} / \mathrm{tahun}$ hal ini menunjukan kenaikan hanya sekitar 3 $\mathrm{kg} / \mathrm{kapita} / \mathrm{tahun}$. Jika dibandingkan dengan malaysia yang hanya memiliki panjang garis pantai $4.675 \mathrm{~km}$ saja Indonesia masih kalah tingkat konsumsi ikannya tahun 2010 sebesar 55,4 kg/kapita/tahun sedangakan tahun 2015 mencapai $70 \mathrm{~kg} / \mathrm{kapita} / \mathrm{tahun}$. Terlebih jika dibandingkan sama negara Korea, Cina, Jepang sudah mencapai 140 $\mathrm{kg} / \mathrm{kapita} / \mathrm{tahun}$.

Fase anak-anak merupakan fase yang paling penting untuk tumbuh kembangnya. Jika anak sekolah mengalami kekurangan protein maka akan berakibat terhambatnya pertumbuhan fisik karena pada usia ini pertumbuhan anak terutama pertambahan tinggi badan sangat pesat dan untuk itulah diperlukan protein. Selain itu, kekurangan asupan protein pada anak usia sekolah juga akan berakibat pada terhambatnya perkembangan sel otak karena otak membutuhkan protein untuk membangun dan menjaga sel-sel otak. Anak sekolah yang kekurangan protein akan mempunyai daya tahan tubuh yang kurang, karena protein dibutuhkan untuk antibodi atau kekebalan tubuh terhadap penyakit.

Peran orang tua pada fase anak sangat penting dalam mengenalkan rasa ikan dan olahannya. Pengenalan mengenai rasa makanan sangat dibutuhkan dalam perkembangan anak agar dapat mengenali berbagai macam rasa makanan. Pada fase ini anak-anak dianggap telah mampu mengekspresikan kesukaannya terhadap jenis makanan tertentu dan memberikan alasan mengapa tidak menyukai jenis makanan tertentu dan telah mampu berkompromi dengan orang tua mengenai menu makanan yang akan dipilih. Salah satu jenis ikan yang mudah didapat yaitu ikan Lele. Akan tetapi penyajian dari ikan Lele hanya berupa digoreng dan disayur.

Sekolah Alam Banyu Belik (SABB) merupakan sekolah berbasis islam yang mengedepankan kemandirian bagi siswa. Jumlah siswa yang dimiliki oleh SABB sebanyak 57 anak dengan rincian 2 siswa baby daycare, 18 siswa TK dan 37 siswa SD. Dari ke-37 siswa SD tersebut terdapat 4 "anak special". Pendidikan yang diterapkan pada sekolah tersebut yaitu bersifat tematik. Salah satu kegiatan rutin bulanan yang dilakukan sekolah yaitu cooking class yang diikuti oleh seluruh siswa SABB (Gambar 1). Kegiatan ini bersifat aplikatif dan dapat melatih kemandirian siswa. Contoh hasil cooking class yang pernah dilakukan yaitu pembuatan es dawet, kolak pisang ataupun 
ubi, sayur lodeh, bolu kukus dan lain sebagainya.

SABB terletak di desa Karang Nangka, Kecamatan Kedung Banteng, Kabupaten Banyumas dan dapat ditempuh dalam kurun waktu sekitar \pm 20 menit dari pusat kota Purwokerto. Wilayah ini merupakan sentra perikanan air tawar. Jenis ikan air tawar yang banyak terdapat disana yaitu Ikan Lele.

Minimnya pengetahuan tentang diversifikasi produk ikan lele dan pengusaan teknologi pengolahan ikan menyebabkan semakin rendahnya nilai jual ikan pada saat musim panen melimpah. Disamping itu keyakinan sensoris meliputi kepercayaan yang dapat dirasakan oleh indera seperti ikan memiliki bau yang amis dan memiliki duri yang diduga dapat menurunkan nilai kegemaran akan makan ikan. Salah satu cara untuk menghadapi permasalahan tersebut yaitu dengan mengolah daging ikan lele menjadi produk olahan berupa nugget ikan lele.

Tujuan dari kegiatan pengabdian masyarakat ini yaitu meningkatkan kegemaran anak akan makan ikan dan transfer informasi terhadap orang tua mengenai cara pembuatan nugget ikan lele yang sehat, tanpa bahan pengawet, tanpa MSG dan tanpa tepung. Selain itu output produk yang dihasilkan diharapkan dapat memberikan tambahan berupa pendapatan keuangan keluarga lewat penjualan.

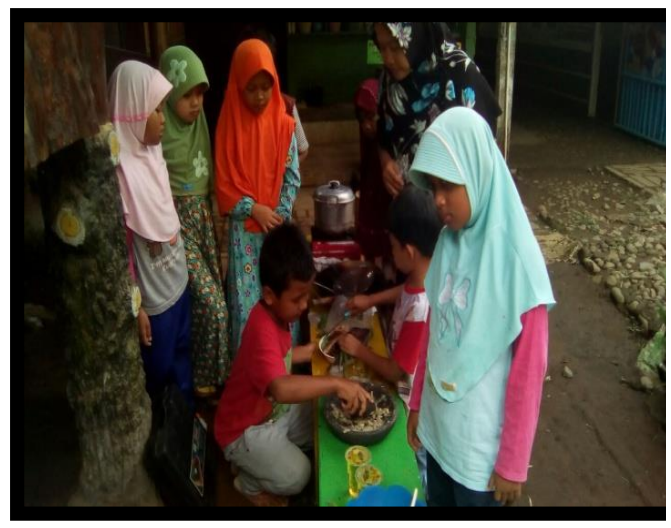

Gambar 1.Kegiatan Cooking Class Siswa SABB

\section{Pelaksanaan Dan Metode}

Tahapan-tahapan yang dilakukan dalam pelaksanaan PKM tertera pada gambar 2 .

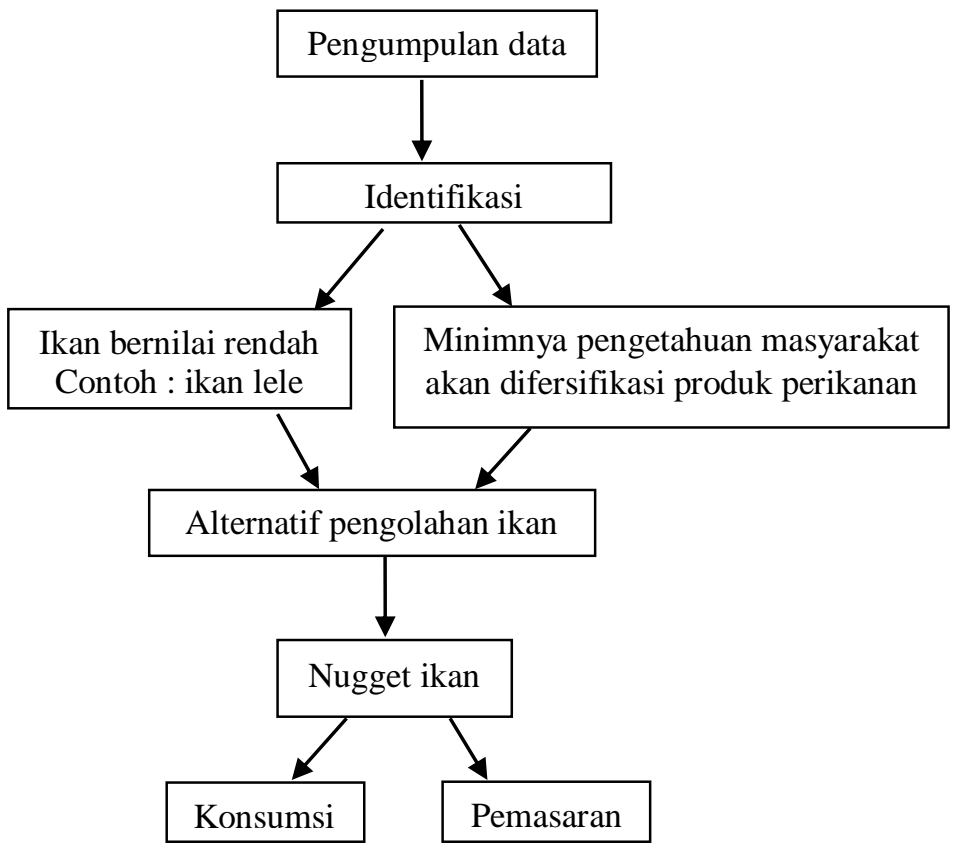

Gambar 2. Tahapan PKM

Model pemberdayaan yang dipakai dalam mentransfer ilmu dan teknologi pengembangan produk olahan nugget ikan menggunakan metode pendampingan praktek langsung di lapangan mulai dari proses persiapan bahan baku sampai pada pemasaran produk yang melibatkan Dosen Pembimbing Lapangan (DPL), mahasiswa, masyarakat (siswa SABB dan orang tua).

Proses transfer teknologi diawali dengan melakukan pembekalan kepada mahasiswa peserta PKM. Materi persiapan dan pembekalan PKM yang perlu diberikan kepada mahasiswa yaitu :

1. Pengetahuan yang cukup tentang cara membuat nugget ikan.

2. Pembekalan mengenai manajemen usaha.

3. Pengetahuan yang memadai mengenai pemberdayaan masyarakat.

4. Pengetahuan mengenai cara bersosialisasi dengan masyarakat. 
Proses pembuatan nugget secara rinci mencakup beberapa tahapan, yaitu

\section{Penimbangan bahan}

Semua bahan yang digunakan dalam proses pembuatan nugget ikan lele ditimbang dengan benar agar tidak terjadi kesalahan dalam pembuatan nugget.

2. Penyortiran

Ikan lele yang telah ditimbang, kemudian disortir dengan tujuan memisahkan daging ikan lele dari duri, kotoran, dan kepala ikan setelah itu dilakukan pencucian.

\section{Pengukusan I}

Pengukusan dilakukan dengan tujuan memudahkan pemisahan duri yang masih tertinggal pada daging. Ada 2 cara pengukusan ialah uap panas langsung terkena bahan makanan atau uap panas tidak langsung kontak dengan makanan (Maryati, 2000). Pengukusan adalah proses pemanasan yang bertujuan menonaktifkan enzim yang akan merubah warna, cita rasa dan nilai gizi. Pengukusan dilakukan dengan menggunakan suhu air lebih besar dari $66^{\circ} \mathrm{C}$ dan lebih rendah dari $82^{\circ} \mathrm{C}$. Pengukusan dapat mengurangi zat gizi namun tidak sebesar perebusan.

\section{Penggilingan}

Dilakukan untuk memperkecil ukuran daging ikan lele. Proses penggilingan pada pembuatan nugget dilakukan dengan menggunakan tangan. Hal ini juga sebagai kontrol apakah ada duri yang tersisa pada daging.

\section{Pencampuran bahan}

Pencampuran semua bahan dalam pembuatan nugget meliputi bahan utama yaitu daging ikan lele dan bahan tambahan seperti bumbu-bumbu, tepung panir dan telor sebagai bahan pengikat, kemudian dilakukan pengadukan hingga adonan tercampur rata atau homogen.

\section{Pengukusan II}

Adonan dimasukkan kedalam loyang kotak dan dilakukan pengukusan. Pengukusan bertujuan membuat bahan makanan menjadi masak dengan uap air mendidih. Pemanasan pada saat pengukusan terkadang tidak merata karena bahan makanan dibagian tepi tumpukan terkadang mengalami pengukusan yang berlebihan dan bagian tengah mengalami pengukusan lebih sedikit (Laily, 2010). Pengukusan menyebabkan terjadinya pengembangan granula-granula pati yang disebut gelatinisasi. Gelatinisasi merupakan peristiwa pengembangan granula pati sehingga granula tersebut tidak dapat kembali seperti keadaan semula (Winarno, 2004). Pengukusan dilakukan dengan waktu 30 menit dengan maksud agar adonan menjadi padat sehingga mudah dipotong kecil-kecil $(1 \times 1 \times 6 \mathrm{~cm})$.

7. Pemaniran

Pemaniran merupakan proses yang harus dilakukan dalam pembuatan nugget yang mempunyai dua tahapan yaitu pencelupan adonan nugget yang sudah dipotong pada putih telur dan pelumuran tepung roti. Tahapan yang pertama merupakan pencelupan nugget yang sudah dipotong pada putih telur dengan tujuan agar tepung roti dapat menempel pada nugget. Pelumuran tepung roti menjadi tahapan yang kedua dan merupakan bagian yang paling penting dalam proses pembuatan produk pangan beku dan industri pangan yang lain. Pelumuran tepung roti dapat membuat produk menjadi renyah, enak dan lezat. Nugget termasuk salah satu produk yang pembuatannya menggunakan proses pemaniran. Tepung roti yang digunakan sebaiknya tidak tengik, wadahnya masih dalam keadaan baik, memiliki bau khas tepung, dan waktu kadaluarsanya masih lama (Alamsyah, 2007).

\section{Hasil dan Pembahasan}

\section{Persiapan Kegiatan}

Kegiatan persiapan pertama yang dilakukan adalah penentuan lokasi kegiatan pengabdian masyarakat sosialisasi gemar makan ikan, praktek dan pembagian hasil olahan ikan (nugget ikan lele). Kegiatan pengabdian kepada masyarakat dilaksanakan di Sekolah Alam Banyu Belik. Setelah penentuan lokasi kegiatan, 
dilakukan penjajagan kesediaan pelaksanaan kegiatan dengan pengiriman surat permohonan pelaksanaan kegiatan pengabdian kepada masyarakat yang ditujukan kepada Kepala Sekolah Alam Banyu Belik. Berdasarkan surat tersebut, Kepala Sekolah memberikan ijin untuk pelaksanaan kegiatan pengabdian masyarakat di sekolah pada tanggal 28 Agustus 2018.

\section{Pelaksanaan Sosialisasi Gemar Makan} Ikan

Kegiatan pengabdian kepada masyarakat "Pengolahan Ikan Lele Bernilai Ekonomi Rendah Menjadi Produk Nugget Yang bergizi dan Bernilai Ekonomi Tinggi, telah dilaksanakan pada hari Selasa, 28 Agustus 2018 dari pukul 09.00 - 11.00 WIB. Kegiatan diikuti oleh 65 orang yang terdiri dari 20 siswa PAUD, 37 siswa SD dan 8 guru pendamping. Secara umum kegiatan sosialisasi gemar makan ikan dilaksanakan dengan cara presentasi dan pemutaran film yeng bermateri pentingnya mengkonsumsi ikan sebagai upaya peningkatan gizi bagi anak (Gambar 3).

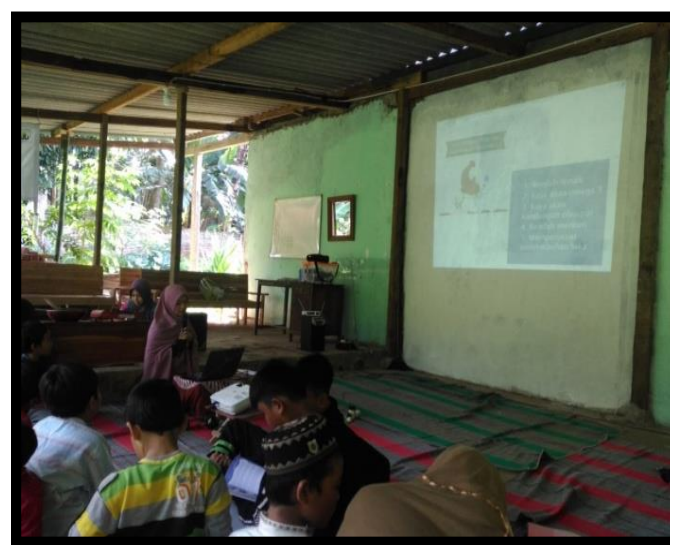

Gambar 3. Pelaksanaan Kegiatan Sosialisasi Gemar Makan Ikan

\section{Pengisian kuesioner}

Setelah acara sosialisasi gemar makan selesai, kita membagikan kuesioner kepada seluruh siswa SD terdiri dari 7 pertanyaan. Pertanyataan 1. Apakah kamu suka makan ikan?; 2. Apakah kamu suka makan daging ayam?; 3. Pernahkah kamu makan nugget ikan?; 4. Pernahkah kamu makan ikan lele?; 5. Seandainya lele diolah menjadi nugget, apakah kamu ingin mencoba makan?; 6. Setujukah kamu kalau ikan itu bisa membuat alergi?; 7. Ikan termasuk protein hewani, menurut kamu pentingkah kita mengkonsumsi ikan setiap hari?.

Hasil yang diperoleh tertera pada grafik berikut:

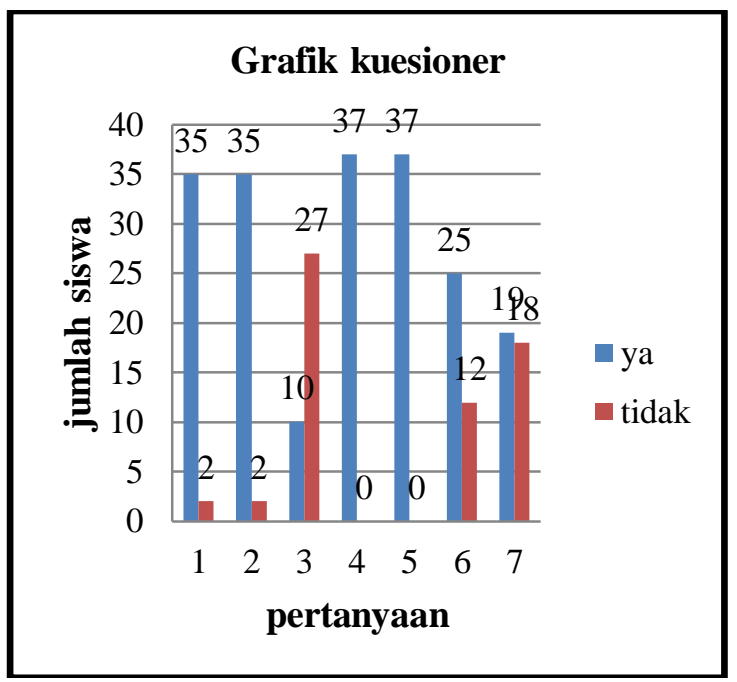

Gambar 4. Grafik data kuesioner

Berdasarkan gambar 4 dapat diketahui bahwa anak SABB suka makan daging ikan dan daging ayam (pertanyaan nomor 2 dan 4). Akan tetapi kebanyakan siswanya belum pernah makan nugget ikan (pertanyaan nomor 3). Diduga penyajian produk ikan tersebut masih berupa makanan olahan sederhana misalnya digoreng atau dimasak dengan menggunakan kuah (soup). Hal ini diperkuat dengan antusiasme seluruh siswa untk mencoba makan nugget ikan lele (pertanyaan nomor 5) meski mereka semua pernah makan ikan lele. Oleh karena itu pengeolahan produk perikanan menjadi bentuk nugget dapat meningkatan kegemaran akan makan ikan. Sejalan dengan penelitian penelitian Parmeswari (2018), makanan berbahan ikan dapat lebih digemari anak usia sekolah dengan penyajian yang lebih inovatif, salah satunya melalui pembuatan makanan selingan (snack) berbahan dasar ikan, sehingga tingkat konsumsi ikan masyarakat 
Indonesia pada umumnya dapat menjadi lebih baik.

Sebagian besar siswa SABB setuju bahwa ikan dapat memicu timbulnya alergi (Gambar 4 pertanyaan nomor 6). Berbagai macam makanan dapat menjadi penyebab bagi munjulnya alergi pada orang disebabkan orang tersebut mempunyai bakat alergi atau bakat atropik. Secara umum, ikan yang bisa menyebabkan alergi merupakan jenis ikan laut yang masuk kedalam kategori ikan scrombroid. Pada tubuh ikan terdapat bakteri yang menyebabkan kualitas berkurang. Bakteri tersebut tersebut ada pada golongan ikan scrombroid, seperti ikan tuna, cakalang dan tongkol yang dapat mengandung histamine apabila penanganan ikan tersebut setelah ditangkap tidak ditangani dengan benar. Daging ikan pada awalnya tidak mengandung histamine, tetapi mengandung histidin. Setelah ikan mengalami kematian, maka dekarboksilasi histidin akan menjadi histimin. Orang yang memiliki bakat alergi ikan, meski pun mengkonsumsi ikan yang masih segar tetap bisa terkena alergi karena reaksi alergi itu timbul akibat adanya protein pada ikan. Sedangkan orang yang tidak mempunyai bakat alergi ikan, juga bisa terkena jika dirinya mengkonsumsi ikan yang disimpan lama dan diawetkan. Menurut Candra et al., (2011), kejadian alergi makanan dipengaruhi oleh genetik, umur, jenis kelamin, pola makanan, jenis makanan dan faktor lingkungan.

Pada pertanyaan no 7 siswa SABB ditanya tentang pentingkah mengkonsumsi ikan setiap hari. Ada 19 anak menjawab iya dan 18 anak menjawab tidak. Menurut saya mengkonsumsi ikan setiap hari tidak ada masalah, asalkan jenis ikan yang dipilih tergolong aman misalnya aman dari limbah merkuri. Namun demikian, orang tua juga harus mempertimbangkan kelengkapan variasi nutrisi anak dengan asupan zat lainnya misalnya sayuran dan buah-buahan. Menyajikan ikan sebagai pilihan menu makanan adalah cara sehat dan tepat untuk memenuhi kebutuhan nutrisi seluruh keluarga. Pastikan makan ikan dengan jenis porsi yang tepat agar mendapat manfaat yang tepat. Menurut Nurjanah (2015), ikan menyumbang protein sebanyak 19,1 g per hari atau $82 \%$ total asupan protein pangan hewani.

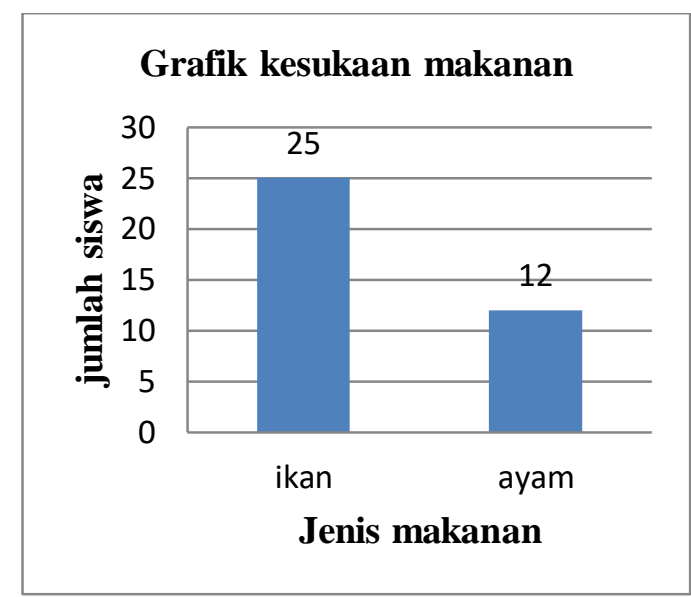

Gambar 5. Grafik Kesukaan Makanan

Pada gambar 5 menunjukan bawah siswa SABB lebih menyukai makanan berupa ikan daripada ayam. Hal ini mungkin disebabkan tekstur akan daging ikan yang lembut sehingga akan lebih mudah dicerna. Akan tetapi ada beberapa siswa yang menyebutkan tidak suka makan ikan karena baunya yang amis dan terdapat duri. Menurut Pratisti (2019), dalam penelitiannya beberapa faktor yang diduga mempengaruhi konsumsi ikan pada konsumen muda secara signifikan adalah : konsumsi ikan dimasa kanak-kanak, sikap, kesadaran kesehatan, tekanan sosial, cara pengolahan dan penyajian, serta harga. Selain itu keyakinan sensoris meliputi kepercayaan yang dapat dirasakan oleh indera seperti ikan memiliki bau yang amis, memiliki rasa yang enak, ikan memiliki sisik, dan memiliki tekstur daging yang lembut. Sehingga diperlukan usaha pengolahan produk perikanan yang baik untuk menghilangkan bau amis, meminimkan adanya duri dan aman dikonsumsi.

\section{Pembagian Pin (souvenir)}

Setelah dilaksanakan penyampaian materi PKM oleh tim pengabdian kepada masyarakat, kegiatan selanjutnya yang 
dilakukan adalah pembagian pin yang berisi ajakan makan ikan kepada para seluruh siswa dan guru yang hadir (Gambar $6)$.

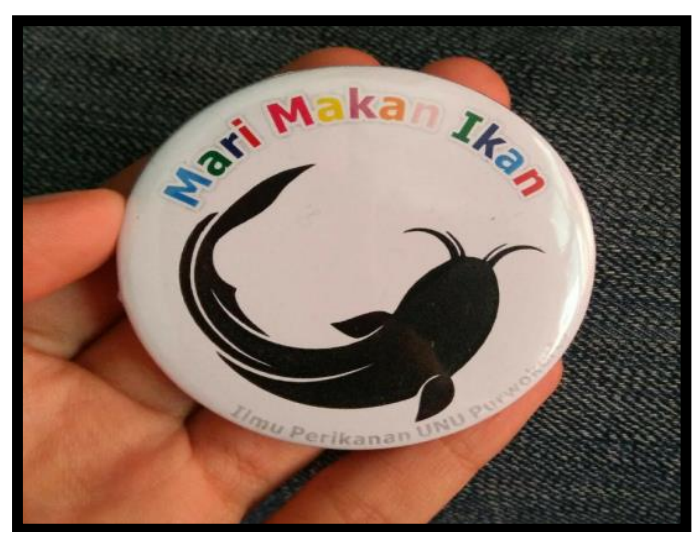

Gambar 6. Pin Gemar Makan Ikan

\section{Praktek Pembuatan Nugget Ikan Lele dan Pembagiannya}

Kegiatan berupa pengabdian kepada masyarakat yang bertujuan untuk anjuran mengkonsumsi makanan olahan ikan ini diakhiri dengan praktek pembuatan nugget ikan lele dan pembagiannya kepada para siswa dan guru dengan harapan memberikan pemahaman kepada para siswa yang mengikuti kegiatan mengenai tingginya nilai gizi makanan yang berbahan dasar ikan (Gambar 7).

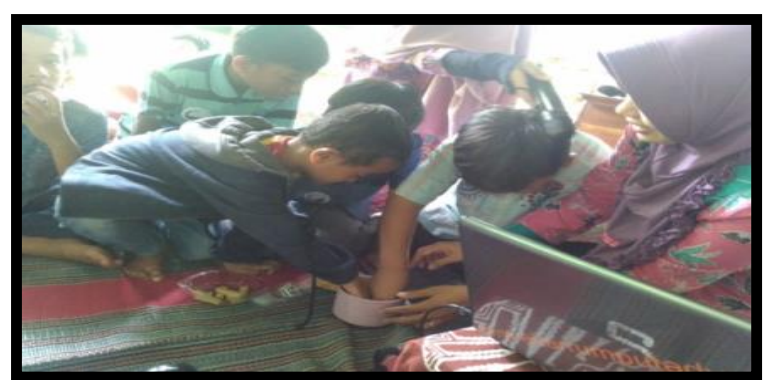

A

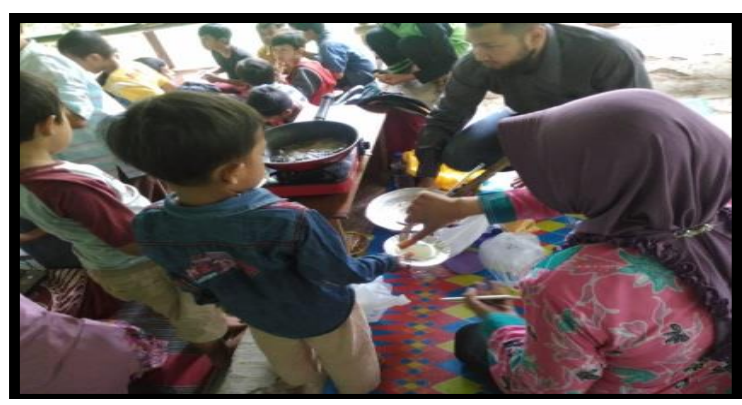

B
Gambar 7. A. Praktek Pembutan Nugget; B. Pembagian Nugget

\section{Hasil luaran yang dicapai}

Hasil luaran yang dicapai berupa pemasaran produk nugget ikan lele dari salah satu orang tua wali murid SABB yang telah mengalami pembinaan (Gambar 8). Adapun hasil binaan produknya sebagai berikut :

1. Produk

Produk yang akan dihasilkan dalam diversifikasi olahan ikan lele adalah nugget lele dengan merk "Mommy's Kitchen, Nugget Lele". Komposisi dari nuget lele ini terdiri dari daging lele segar, bumbu-bumbu alami, non pengawet, non MSG dan tidak menggunakan terigu. Penggunaan daging lele segar dengan bumbu-bumbu alami serta tanpa bahan kimia, cocok untuk kalangan anak-anak maupun dewasa yang memiliki penyakit alergi daging ayam ataupun ikan laut. Produk ini dikemas dengan menggunakan paper bowl yaitu wadah kertas berbentuk mangkok dengan tujuan mengedukasi masyarakat dalam meminimalkan sampah plastik.

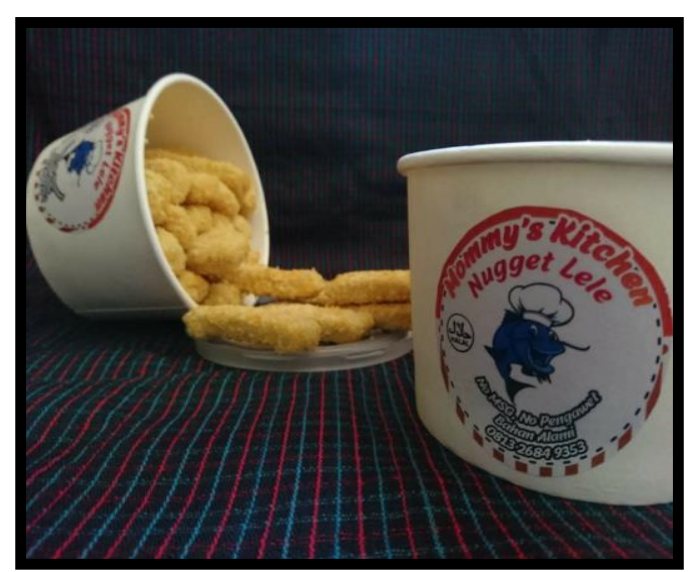

Gambar 8. Produk Hasil Binaan

2. Harga

"Mommy's Kitchen, Nugget Lele" dijual dengan harga Rp.30.000 per pack. Penetapan harga ini mengacu pada harga pesaing dan harga pokok penjualan.

3. Tempat 
Lokasi produksi nugget lele ini berada di Jalan Kauman Lama, Purwokerto. Pemilihan lokasi berdasarkan pada letak lokasi tersebut berada ditengah kota. Sehingga akan memudahkan dalam pemasaran. Selain itu, keunggulan dari lokasi ini yaitu sangat strategis karena berada dekat dengan instansi pendidikan, toko-toko, rumah warga serta kos atau asrama, serta sekeliling area tersebut terdapat banyak masyarakat yang menyukai makanan praktis.

4. Promotion

Proses promosi dilakukan dengan menggunakan media sosial seperti whatsApp.

\section{Simpulan}

1. Diversifikasi produk olahan ikan perlu dilakukan sebagai upaya yang baik dalam membentuk sikap yang positif pada anak usia sekolah terhadap konsumsi ikan. Setelah dilakukan pengisian data kuesioner seluruh siswa tertarik untuk membuat nugget ikan lele hal ini menunjukan bahwa penyajian yang lebih inovatif, merupakan salah satu cara meningkatkan gemar makan ikan.

2. Hasil olahan ikan berupa nugget ikan lele dapat memberikan pendapatan tambahan dalam rumah tangga.

3. Perlu dilakukan kegiatan promosi gemar makan ikan pada daerah atau wilayah lainnya agar dapat meningkatkan kesadaran masyarakat untuk gemar mengkonsumsi ikan pada menu sehari-hari, sehingga tingkat konsumsi ikan masyarakat Indonesia pada umumnya dapat lebih baik.

\section{Saran}

Berdasarkan tanggapan dan hasil pengisian kuesioner peserta pengabdian, maka untuk meninggkatkan kegemaran makan ikan disarankan agar para orang tua dapat mengembangkan ide kreativitasnya dalam mengembangkan diversifikasi produk perikanan. Untuk selanjutnya diharapkan agar pelatihan serupa dapat dilakukan kembali dengan peserta (audience) yang lebih banyak lagi.

\section{Ucapan Terimakasih}

Terima kasih disampaikan kepada LPPM UNU Purwokerto yang telah mendanai keberlangsungan Pengabdian Kegiatan Masyarakat.

\section{Daftar Pustaka}

Alamsyah, Y. 2007. Aneka Nugget Sehat nan Lezat. Agromedia Pustaka. Depok.

Chandra, Y., A. Setiarini dan I. Rengganis. 2011. Gambaran sensitivitas Terhadap Alergen Makanan. Makara, Kesehatan : Vol. 15 No. 1, Juni 2011 : 44-50.

Effendie, I.M. 2002. Biologi Perikanan. Yayasan Pustaka Nusantara, Yogyakarta.

WHO. 2003. Diet, Nutrition, and The Prevention of Chronic Disease, Technical Report Series 916 of a Joint FAO/WHO Expert Consultation, WHO, Genewa.

Erawan, E Dan K.M. Boer. 2018. Analisis Efektivitas Sosialisasi Program Gemarikan Oleh Bidang Pengolahan Dan Pemasaran Hasil Perikanan (P2HP) Di Dinas Kelautan Dan Perikanan Provinsi Kalimantan Timur Dikota Samarinda. Jurnal Ilmu komunikasi. Vol 6 (2) : 125-136. ISSN 2502-597X.

Laily, R. 2010. Olahan dari Kentang. Yogyakarta. Kanisius.

Maryati, S. 2000. Tata Laksana Makanan. Jakarta : Rineka Cipta.

Prameswari, G. N. 2018. Promosi Gizi Terhadap Sikap Gemar Makan Ikan Pada Anak Usia Sekolah. Journal Of Health Education : Vol 3 (1) : $1-6$. $\begin{array}{llll}\text { ISSN } & 2527 & - & 4252 .\end{array}$ 
https://Journal.Unnes.Ac.Id/Sju/Index.P hp/Jhealthedu

Prastiti, C. 2017. Model Konsumsi Ikan Pada Konsumen Muda [Studi Di Yogyakarta]. REKOMEN (Riset Ekonomi Manajemen). ISSN 25808893. 15 hal.

Winarno, F. G. 2004. Kimia Pangan dan Gizi. Jakarta: Gramedia Pustaka Utama. 